\title{
THE SALAFI WORLDVIEW AND THE HERMENEUTICAL LIMITS OF MAINSTREAM \\ SUNNI CRITIQUE OF JIHADIST-SALAFISM
}

\section{Post-review version published in Studies in Conflict and Terrorism as per this link:}

https://www.tandfonline.com/doi/full/10.1080/1057610X.2018.1529359

Adis Duderija (Ph.D), Lecturer in Islam and Society, Griffith University, a.duderija@griffith.edu.au

\section{INTRODUCTION}

A number of theological rebuttals of jihadist-salafi interpretations of Islam have been penned by mainstream Sunni ${ }^{i}$ scholars, especially since the tragic events of $9 / 11 .{ }^{\text {ii }}$ These efforts have intensified with the rise of the "Islamic State" (IS) with additional fatwas being issued. These fatwas have primarily problematized the theological and/or juristic reasoning behind the violent actions resorted to by jihadist salafis such as suicide bombings and the killing of innocent civilians (non-combatants) as "unislamic." iii

The aim of this paper is not to directly engage with this literature but to point to the hermeneutical limits of the critique of mainstream Sunnism vis-a-vis the jihadist-salafi interpretations with particular reference to the literature produced by the proponents of the Islamic State (IS). The main argument the article makes is that by subscribing to what will be termed a 'salafi worldview,' mainstream Sunnism shares many interpretationally crucial epistemological and methodological mechanisms with those adopted by the proponents of the ideology behind the IS. As such mainstream Sunnism has strong hermeneutical limits that do not allow it to be in a position to mount an interpretationally effective rebuttal of many beliefs and 
practices jihadist-salafis resort to including those pertaining to apostasy, enslavement and gender related issues.

Since the main argument of the article hinges critically upon an accurate understanding of what constitutes this 'salafi worldview," the first part of the article will deal with the description and explanation of what this concept means from the perspective of the Islamic intellectual history. In this respect the origins and functions of the salafi worldview are identified and discussed in relation to the salafi worldview as:

1. a particular conceptualisation of the Islamic intellectual tradition (turath)

2. a heavily textualist-oriented epistemology;

3. an expression of and an attempt at re-enacting and bringing about the utopian sacred past

4. the subscription to the idea of the retrogressive nature of time and history

5. an affirmation of the theological doctrine of " adalat as-Sahaba".

Once this careful deconstruction of the concept of the "salafi worldview" and its constitutive parts has been accomplished, the second part of article will provide evidence of how the mode of reasoning and the scriptural hermeneutics-based justifications provided for resorting to certain practices and beliefs in the IS literature, are premised on this very logic underpinning the salafi worldview, that are also shared by the proponents of mainstream Sunnism. Hence, the hermeneutical limits of mainstream Sunnism's critique of jihadist-salafi ideology. Therefore, I argue that understanding the 'salafi worldview' nature of mainstream Sunnism is imperative if we are to effectively counter the religious narrative/s promoted by the jihadist-salafi groups such as the IS. 


\section{THE CONCEPT OF THE ISLAMIC TRADITION (TURATH) IN MAINSTREAM SUNNISM}

To understand one aspect of the salafi worldview element of mainstream Sunnism we need to understand how it conceptualises the concept of the Islamic intellectual tradition (turath) itself and its nature.

In its broader sense, turath in the Islamic Sunni tradition can be characterized as a fluid, dynamic, and cumulative religio-historic construct with a central intellectual core, primarily the Qur'an and Sunna, and a number of later developed doctrines derived from its core pertaining to philosophy, theology, ethics, jurisprudence, legal theory, and mysticism, as well as certain sociological and political attitudes and notions. ${ }^{\text {iv }}$

In an epistemologically more narrow sense turath is usually linked to concepts such as continuity, stability, authenticity and authority. It literally means 'handing over' of Islamic practices and beliefs. ${ }^{\mathrm{v}}$ This narrower conceptualisation of the turath emphasises the idea of intergenerational and personal connectedness (ittisal) with what is considered to be the sacred past and its origins and has been "a persistent value in Muslim thought and institutions over the centuries." ${ }_{\mathrm{vi}}$ Graham argues that the phenomenon of what he terms the 'paradigm of isnad' that is very much a distinctive feature of mainstream Sunnism, as for example, employed in classical hadith sciences or books of jurisprudence (and one could argue in a different form, namely silsala, in that of Sufism). As such, this isnad-based aspect of the turath exemplifies well the centrality of the concept of connectedness as its defining feature. It is important to highlight that this concept of ittisaliyya, to borrow Graham's neologism in Arabic, has very strong 
epistemological foundations, a point to which we will turn in the following sections. ${ }^{\mathrm{vii}}$ Based on this narrower understanding of the concept of turath, a salafi worldview is strongly shaped by the 'paradigm of isnad' and the ideas of continuity, stability, authenticity and authority.

It is also important to highlight at this juncture that the turath and its main concepts are a contested terrain, and that various Islamic groups from the past and the present, can conceptualise them differently but often with important overlaps. ${ }^{\text {viii }}$ Hence, various groups have attempted to appropriate the turath by claiming that their interpretations and conceptualisations are the most authentic and authoritative in contrast to the competing ones (Ibid.). As argued below, it is in this context that we can make sense of the meaning, origins and the function of the salafi worldview in mainstream Sunnism and why and how it is appropriated by jihadist salafi groups such as the IS.

\section{NATURE OF TRADITIONAL ISLAMIC EPISTEMIC SCHEMES IN MAINSTREAM SUNNISM AND THEIR RELATIONS TO THE SALAFI WORLDVIEW}

Another important dimension of understanding the concept of the salafi worldview in mainstream Sunnism, is its epistemological dimension. Hence, a discussion on the nature of Islamic epistemology and its conceptual relationship to the concept of the salafi worldview is in order.

Following Dahlen, ${ }^{\mathrm{ix}}$ in mainstream Sunnism we can broadly identify the following distinct epistemic schemes, namely:

i.) historical-empirical;

ii.) theological, philosophical and mystical schemes; and 


\section{iii.) 'Juristic-rational'.}

Due to the aims of this article I am only able to discuss the first and the third. It is also worth noting that it is the first and the third epistemic themes that are considered as the core of mainstream mature Sunnism and that others are peripheral to how mainstream Sunnism sees itself and have always been viewed with suspicion and scepticism. ${ }^{x}$ Hence, when referring to mainstream Sunnism in this article I mean the 'historico-empirical' and 'juristic-rational' epistemic schemes in particular that have reached a large degree of hermeneutical stability towards the end of the fifth century of the Islamic calendar. ${ }^{x i}$

According to Dahlen the 'historical-empirical' epistemic scheme is a strongly transmitted science- oriented epistemology ('ulum-ul naqliyya) that bestows to these sciences epistemological priority over that of the rational ones ('ulum-ul 'aqliyya). Hence, for this epistemic scheme, naqli (textualist forms of knowledge, especially the hadith reports are considered epistemologically superior to rational sources of knowledge). ${ }^{\text {xii }}$ This epistemology is particularly prominent among the proponents of the Hanbali school of thought / ahl al-hadith manhaj. ${ }^{\text {xiii }}$

Another epistemic scheme identified by Dahlen is the 'juristic-rational'. It was a result of a kind of reconciliation between the epistemological claims of the 'historical-empirical' scheme and the idea, embraced by the jurists, that non-textual based sources of knowledge were useful in extrapolating, in a logical manner, further truths from those found in the revealed texts. The employment of ijtihad (independent judgement) was permitted insofar as the questions it aimed to find answers to were considered to be left unaddressed in the revealed sources, as the views of 
the Prophet, his major Companions and the supposed consensus of the early Muslim generations were considered as hermeneutically most privileged. Therefore, the jurists were unable to derive or engender any new legal forms but could only engage in law-finding exercise within the epistemic limits explained above. ${ }^{\text {xiv }}$

It is important to note that throughout history and until the present, the 'juristic-rational' scheme was continuously challenged, existed in tension with the historical-empirical scheme, and was becoming increasingly logocentric with logic overshadowing epistemology. In fact, the epistemological tensions and dichotomies between all of the competing epistemic schemes have and continue to exist throughout Islamic history. ${ }^{\mathrm{xv}}$

In the context of describing the historico-empirical and juristico-rational traditional Islamic epistemic schemes, Dahlen referred to their past-oriented, heavily textualist epistemological rationalisations and justifications of normative views and legal determinations. ${ }^{\text {xvi }}$ In mainstream Sunnism, this view has found expression in the idea of following in the footsteps of the righteous early generations of Muslims known as the as-salaf as-salih(discussed more below), which is a major element of the concept of the salafi worldview as employed in this chapter. To understand this aspect and function of Salafi worldview and its epistemological implications, it will be necessary to elaborate on the early Muslim history and the very nature of Islamic law in mainstream Sunnism.

Early Muslim history was characterised by a number of very significant, and, for subsequent generations of Muslims, traumatic schisms of both theological and political in nature. As a result, a number of competing theological and political doctrines among Muslims emerged, 
which posed not only a very significant political, but also salvific problem for subsequent generations of Muslims who were keen on establishing the correct parameters of doctrines, beliefs and practices considered to be in accordance with the Qur'an and the Sunna of the Prophet. One aspect of this struggle for religious legitimacy among the post as-salaf as-salih Muslims was by means of linking one's theological, political or legal views to that of the assalaf as-salih. Given the nature of the concept of turath discussed above, this intergenerational linking, especially though the paradigm of isnad, would ensure that these (competing) factions could claim continuity with the tradition and hence their views would/could be considered as authoritative and credible.

In this context, the concept of the salafi worldview can also be conceptualised in terms of the idea of the 'emulation-worthiness' of the first century religious and political authorities, who were considered as having remained faithful to the teachings of the Qur'an and the example of the Prophet (i.e. Sunna) in relation to aqida (beliefs), manhaj and ibada (worship), in contrast to those that are deemed (from a perspective of a particular group of Muslims) to have deviated from them. Moreover, towards the end of the second Islamic century, this salafi worldview started to shape the epistemological boundaries of Islamic thought, especially in relation to the increased importance of Sunna and its documentation in the form of hadith. In this respect, in Sunnism a methodology that was developed to authenticate the Sunna depended entirely epistemologically on upholding the unblemished character of all of the Prophet's Companions (in the armed conflicts between Muslims that have taken place after his death) and was justified theologically on the basis of a doctrine known as Murji'ism. We will return to this point in the 
context of discussing a related concept/doctrine, known in the literature under the phrase "adalat al-sahaba" (i.e. moral uprightness of the Companions of the Prophet) and its role and function in the salafi worldview in a separate section below.

The epistemological importance of the salafi worldview is evident, for example, from the fact that the founders or initiators of the various Islamic sciences sought the ideas and the views among the as-salaf as-salih as intellectual antecedents in order to bestow legitimacy to their respective disciplines. ${ }^{\text {xvii }}$ In this context Goldziher asserts that:

As such the imitation of the salaf, the pious ancestors who formed their habits under the eyes and on the example of the prophet, became the ideal of pious Muslims. Gradually, Salafi, i.e. the one who imitates his ancestors, becomes the supreme title of praise in pious society. ${ }^{\text {xviii }}$

Indeed, we find the epithet 'salafi' as designating a person who is pious or possessing various kinds of noble characteristics and virtuous features (but not a developed legal theory or systematic theology as claimed by some Muslim groups) frequently in the writings of various Muslim scholars. ${ }^{\mathrm{xix}}$

The centrality of this concept of the imitation of the salaf in the mainstream Sunni Islamic tradition can be further gleaned from the fact that Muslim scholars' views regarding the salaf has always had and continues to have significant implications regarding whether or not their views could be considered part of Sunni orthodoxy, as "any Sunni theologians aspiring to 
transcend (what they took to be) the salaf's way in religion had to justify such transgression to their contemporaries and to themselves." $\mathrm{xx}$

This salafi worldview also had a profound effect on the nature of Islamic law. In essence, Islamic law can be characterised as being a discourse embedded in the larger oral-based frame-work that privileges 'authoritative parlance', to use Souaiaia's phrase, of certain individuals (such as the Prophet Muhammad, Caliphs, and founders of the major legal schools of thought ( madhahib) who are considered to be authoritative by the Muslim community. ${ }^{x x i}$ In other words, as with other elements of salafi worldview discussed above, the authority in Islamic law is first and foremost epistemic in nature. ${ }^{\text {xxii }}$ As a result of the (legal) reasoning (ijtihad) of authoritative individuals over time, accumulation of legal precedents took place and became considered as binding on the Muslim community in general because these were seen to be in accordance with the teachings of the Qur'an and the Sunna. This, in turn, gave rise to the concept of taqlid. Taqlid is a hermeneutical mechanism, whereby, rather than abandoning existing legal theory rules in favour of a new hermeneutic, a jurist develops new interpretations within the framework of the established madhhab-based hermeneutic. This legal mechanism's primary purpose was to ensure that the legal opinion of the jurist is able to gain wide acceptance by embedding it into the 'sacred past'xxiii, which as shall be argued below, is another major constituting element of the concept of Salafi worldview. For the madhhab-based approach, this consensus of madhhab scholars is the ultimate criterion in determining the compliance or otherwise of a particular legal principle with the Qur'an and the Sunna. ${ }^{\text {xiv }}$ 
The proponents of the historico-empirical episteme, however, reject the broader hierarchical hermeneutic upon which the practice of taqlid is based. Instead, they call for what they consider to be an unmediated return to the Qur'an and Sunna in accordance with their above outlined hermeneutic/epistemic scheme. Taqlid for them is tantamount to innovation, bida' $a$, and a deviation from Sunna. ${ }^{\mathrm{xx}}$ Instead, the proponents of the historico-empirical episteme consider that the uncontested adherence to hadith, termed ittiba, as the sole vehicle for the perpetuation and depository of Sunna, is the only way of remaining truthful to the Prophet's Sunna. ${ }^{\text {xxvi }}$

It is important to highlight that despite the existence of the contestations over who the salaf are ${ }^{\mathrm{xxvii}}$ or how to arrive at their interpretations of the Qur'an and the Sunna, the salafi worldview described in this article so far is shared by both the proponents of the historicoempirical and juristic-rational epistemic themes and is fundamental to mainstream Sunnism.

\section{SALAFI WORLDVIEW AS SACRED PAST}

In the context of discussing the institution of taqlid in the preceding section, the concept of the 'sacred past' was mentioned. The idea of the 'sacred past' is another major element of the salafi worldview and I turn my attention to it now. The concept of a sacred past is, of course, not peculiar to Muslims, as Van Ess, a noted historian of Islam, points out: 
That sort of backward-looking utopian thought is fairly common. In nineteenth-century Europe, it took the form of nationalism; there too, a mythical past was constructed in an effort to forge an identity, and that mythical past was reconstituted through a slanted reading of the historical texts. For Muslims, a further element has been added—namely, revelation, which marks the beginning of historical reality and therefore forms an indelible part of the utopia. ${ }^{\text {xxviii }}$

One of the functions of the salafi worldview is intimately linked to the idea of the preservation of the sacred past. The importance of this concept of sacred past in the Islamic tradition is aptly noted by Anjum:

In a tradition like Islam, defined by moments of divine intervention in human history in a sacred past, that past remains in some ways unsurpassable by definition. The preservation, interpretation, and construction of cultural memory constitute central tasks for the religious elite, which is made even more significant in Islam due to the selfconscious emphasis on the historicity and preservation of Islam's scripture, the Qur'ān. ${ }^{\text {xxix }}$

This aspect of the salafi worldview seems to have emerged in the late second century Hijri. ${ }^{\mathrm{xxx}}$ As exemplified by the definition used by Al-Suyuti, the genesis of this utopian worldview is best understood in light of the political and theological schisms that took place in the Muslim community in the first century Hijrir ${ }^{\mathrm{xxx}}$. This is, for example, evident in the use of phrase as- 
salaf as-salih in treaties attributed to Hasan al-Bașrī (d. 110/728) to support the doctrine of free will, to which he, unlike his interlocutors, considered as being a doctrine espoused by the assalaf as-salih. As it was highlighted above with the other elements of the salafi worldview, such attempts to link one's views to those who are considered to be the very embodiments of the sacred past (i.e. the as-salaf as-salih generations of Muslims) would bestow on the concerned individual/group the aura of authoritativeness and ensure continuity with the turath. The same holds true for the contemporary usages of salafi worldview. ${ }^{\text {xxii }}$ This quest for authenticity and the defence of Sunni thought from foreign forms of reasoning by means of appropriation of the salaf and projection of post as-salaf as-salih's view onto them is aptly described by Anjum as follows:

the superiority and truth of the way of the first few generations of Muslims, the salaf, has been a key theological premise of Sunni Islam, which Sunni ulama have tried to defend against incursions of intellectual sophistication as well as foreign systems of reasoning and spirituality. ${ }^{\text {xxxiii }}$

From a historical point of view, the earliest usage of the term as-salaf as-salih is therefore to be understood as a particular outlook of the post as-salaf as-salih generations of Muslims on the early historical events that took place after the Prophet's death regarding the issues considered unresolved in the Qur'an and Sunna as well as the means of getting to terms with the above mentioned political and doctrinal schisms that plagued the nascent Muslims community. This salafi worldview proved particularly important for the formation of what now is largely considered 'mainstream' Sunnism, in the fourth/fifth century of the Islamic calendar. ${ }^{\text {xxiv }}$ 


\section{SALAFI WORLDVIEW AS RETROGRESSIVE HISTORY}

As noted above, over time, the imitation of the salaf became a very important element of what it means/meant to be a pious Sunni Muslim, as the salaf were considered to embody the correct understanding of the Qur'an and Sunna. One of the important ideas that emerged in the middle of the second century of the Islamic calendar was that was a product of a salafi worldview mindset was the premise that the Sunna of the Prophet could only be preserved and remained faithful to by means of a completely textualist epistemology associated with the classical hadith sciences. ${ }^{\mathrm{xxxv}}$ To understand this intrinsic interlinking between the concept of Sunna and the salafi worldview, let us look at the works of a few scholars who have recognised its importance. In Chaumeont's article on the 'salaf wa-l khalaf' it is stated that:

It was the Sunna, rather than the Kur'an, which instituted one of the most characteristic traits of the Islamic vision of history by imposing the idea a priori that this history was said to have been inevitably followed by a period of relaxation of standards, deviation and finally of division. ${ }^{\text {xxxvi }}$

A similar line of reasoning is espoused by Graham, who argues that Muslim scholars in later times (i.e., post as-salaf as-salih times) developed an explicit concept of fasad az-zaman, or 'the 
degeneration of the times', to covey the idea of the increasing temporal as well as moral distance from the time and the practice of the Prophet and the exemplary early Muslim community (umma). In his words:

The original Ummah is not simply a source of nostalgia for something irrevocably lost, but also a historical model for every society in every age that would be properly Muslim, or submissive to the will of God. The utopian blueprint is available as a realized era of the historical past, which makes it all the more compelling as a realizable possibility in every age. It is a major source of what can legitimately be called a pervasive and recurrent 'traditionalist' bent in Islamic thought, one that looks to this original, ideal model for renewal. In this regard, the Sunnah of the Prophet represents for all practical purposes the sunnah of the original Salaf. ${ }^{\text {xxxvii }}$

In light of Chaumont and Graham's remarks, another important function of the salafi worldview in mainstream Sunnism is also to be conceptualised by means of a particular understanding of the concept of history and time (i.e. their regressive nature), and their relation to the present and future. It is encapsulated by the idea of the imperative of going back to an ideal model of the Prophet's Sunna that only existed in the past, and that was for all purposes embodied in the hadith narrations as authenticated by the classical Muslim hadith scholars such as Imam AlBukhari (d. 870 AD)and Muslim (d. 875 AD). 
This salafi worldview is often justified on the basis of a few hadith, in which Muhammad reportedly asserted that the best people were his generation and then the next following, and so

on. ${ }^{\text {xxviii }}$ As noted by Schulze, this weltanschauung in mainstream Sunnism "sought a timeless aesthetic and intellectual ideal, derived from an origin that was pure of all temporal circumstances" and that it could only locate such ideal at the time of the Prophet and the early Muslim community. ${ }^{\text {xxix }}$

This aspect of the salafi worldview, therefore, defers to the past to provide all the answers, and constantly imposes itself upon the present/future. In other words, the authenticity of Muslim identity can only be established by returning to a fixed point in historical time, that of the Prophet and the early Muslim community. It is important to highlight that this salafi worldview, is a central feature of both iterations of mainstream Sunnism, the historico-empirical and justistic-rational.

SALAFI WORLDVIEW AS AN AFFIMATION OF THE DOCTIRNE OF ADALA ALSAHABA

Another important element of the concept of the salafi worldview is its function of affirming the mainstream Sunni theological doctrine known as adala al-Sahaba. Osman defines the doctrine in the following matter: 
a Companion is anyone who caught a glimpse of the Prophet Muhammad. Knowing the Companions is crucial because they were the transmitters of Islam to subsequent generations. They were considered reliable at the time of the Prophet, as attested by his words and deeds as well as the Qur'an itself. Furthermore, a consensus, made possible by divine grace, prohibits questioning their integrity and reliability or refusing to accept them, for whereas we are certain that God and the Prophet accepted their reliability, we are uncertain that they lost that integrity at a later time. The inconclusiveness of reports about their deeds, particularly their participation in civil wars, does not allow us to pass a valid judgment on them. Therefore, the proper attitude of good Muslims should be to refrain from discussing these reports, interpret them in favor of the Companions as the outcome of a sincere exercise of personal judgment, or simply regard them as lies and distortions. $^{\mathrm{xl}}$

For the purposes of this article we are interested primarily in the epistemological function of the doctrine as reinforcing the elements of salafi worldview discussed above. In many ways all of the elements of the salafi worldview discussed so far hinge upon this doctrine. Namely, the idea of an isnad-based concept of turath with its emphasis on continuity, a heavily textualist epistemology that underpins both the historico-empirical and juristic-rational versions of mainstream Sunnism and the ideas of sacred past and retrogressive history embodied in the concept of following in the footsteps of the salaf ( the first generation of which are the Companions ) as the symbols and embodiments of piety and authority can only be defended 
upon the idea of the (collective) reliability and uprightness of the Companions as "the transmitters of Islam to subsequent generations" (Ibid.). This doctrine is also reflected in the very nature of the Islamic law discussed above which hermeneutically privileges what Souaiaia ${ }^{x l i}$ the "authoritative parlance" of the major authorities of early Islam, especially the major Companions.

\section{THE HERMENEUTICAL LIMITS OF MAINSTREAM SUNNI CRITIQUE OF JIHADIST SALAFISM}

From the above (admittedly long) description of the concept and nature of the Salafi worldview and it main constituents I am now in a position to discuss the hermeneutical limits of mainstream Sunni critique of jihadist Salafism. I will use the examples from the magazine Daqib as a case study. My aim is to demonstrate that the justifications and the reasoning employed in the Dabiq magazine on various issues, including those pertaining to religiously sanctioned violence, are framed on the basis of the salafi worldview described above that is a fundamental feature of mainstream Sunnism. Therefore, my main argument is not that the views in the Dabiq magazine are Islamic or not but that there is a large degree of hermeneutical affinity between the interpretational approaches found in the Dabiq magazine and mainstream Sunnism as they both share the same interpretational, epistemological and methodological commitments inherent in the salafi worldview.

For example, in the second issue of the magazine in the feature article " The Flood of the Mubahala" in the context of refuting the allegations that the proponents of the IS are the 
contemporary Khawarij not only do the proponents of the IS ideology rely heavily on a textualist hermeneutic by making frequent references to Qur'anic verses and the hadith ${ }^{x l i i}$, their entire reasoning is based on the process of referring to the ideas of scholars from the past, including those from the salaf as salih generations such as ibn 'Abbas, ibn Masud, Ibn Awza'i as well as those associated with the Hanbali/Ahl-al hadith school of thought in particular such

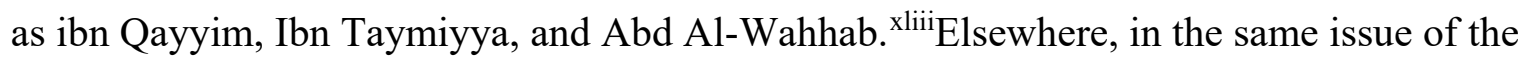
magazine we find direct appropriation of the idea of the 'salaf'. Namely, in the same article the author states that it was the opinion of the salaf that sins are gates leading to disbelief as the ultimate proof for the correctness of his own understanding of an issue under discussion. ${ }^{\text {xliv }}$

In the first issue of Dabiq in the article titled "Imama is from the millat of Ibrahim" the particular concept of imama (i.e. leadership) espoused by the proponents of IS, namely that is both political and religious in nature, is justified on the basis of the following:

- A reference to an entirely textualist based methodology (i.e. Quranic verses and hadith and

- reference to classical Qur'anic exegetes such as Al-Qurtubi and Ibn Kathir ${ }^{\text {xlv }}$

In the third issue of the Dabiq magazine that focuses on calling Muslims to join the caliphate by means of emigration (hijra), the obligatory nature of the hijra is reasoned on the basis of:

- particular reference to Qur'anic verses,

- the views of the Hanbali/ ahl-al hadith scholar Ibn Qayyim and Ibn Taymiyya ,

- Qur'anic exegesis of the Hanbali /ahl-al hadith scholar Ibn Kathir and a few hadith. ${ }^{\text {xlvi }}$ 
Furthermore, in the eight issue of the magazine that revisits the issue of hijra, Muslim women are specifically addressed in an article written by a female author. In the article the idea of hijra being obligatory on Muslim women is argued on the basis of:

- several Qur'anic verses,

- several hadith

- reference to the Qur'anic exegesis of Ibn Kathir

- examples from early Islamic history of women making hijra on their own. xlvii $^{\text {. }}$

In the fourth issue of the magazine in the article "The Revival of Slavery before the Hour' that has attracted a lot of attention (and disgust) in the western media, ${ }^{x}$ lviiithe proponents of the IS ideology are attempting to justify the killing of male polytheists ( mushrikun) and revival of slavery at what they consider to be the near apocalyptic times. In the article they refer to the idea that the "majority of the jurists" xlix have argued that the polytheists are to be killed and their women can be enslaved although other options (including killing) also exist in relation to the women. In the footnote on page 15 the author of the article refers to not only hadith-based evidence but also the views of classical scholars to defend their interpretation. In the footnote it is it is stated as follows

The enslavement of the apostate women belonging to apostate groups such as the rāfidah, nusayriyyah, durūz, and ismā'̄iliyyah is one that the fuqahā' differ over. The majority of the scholars say that their women are not to be enslaved and only ordered to repent because of the hadīth, "Kill whoever changes his religion" [Sahīh al-Bukhārī]. But some of the scholars including Shaykhul-Islām Ibn Taymiyyah and the Ahnāf 
(Hanafis) say they may be enslaved due to the actions of the Companions during the Wars of Apostasy where they enslaved the apostate women. This opinion is one also supported by evidence.......

Then the author of the article goes on to defend the selling of enslaved Yazidi women by the IS members by referring to the practice of Companions and states:

The enslaved Yazidi families are now sold by the Islamic State soldiers as the mushrikīn were sold by the Companions (radiyallāhu 'anhum) before them. ${ }^{\text {li }}$

They further buttress their views on related aspects of revival of slavery by refereeing to a number of hadith as well as the Hanbali/ ahl-al hadith scholar, Ibn Rajab Al-Hanbali and Shafi'i scholar Al-Nawawi. ${ }^{\text {lii }}$ In the ninth issue of the magazine we find another attempt at justifying (sexual) slavery of women by an article written by a female member of the IS. It is written as a response to the criticism levelled against the IS for enslaving Yazidi women and for subjecting them to sexual slavery. The main argument of the article is that sexual slavery of women war captives (saby) is a better alternative to prostitution that men in the West or other Muslims resort to. In the article we find references to a number of hadith which refer to the practice of permissibility of enslaving women of unbelievers and engaging in sexual intercourse with enslaved women among the Companions of the Prophet as well as the hadith reports of Prophet himself engaging in the same. The justifications is explained in the following terms: 
The Sahābah and their followers in goodness treaded upon the path of the Prophet (sallallāhu 'alayhi wa sallam) after him. Therefore, we almost cannot find a companion who didn't practice saby. 'Alī Ibn Abī Tālib (radiyallāhu 'anh) had nineteen slave-girls. Ibn 'Uyaynah reported that 'Amr Ibn Dīnār said, “'Alī Ibn Abī Tālib wrote in his will. liii

The article goes on to express amazement at the Muslim scholars who have criticised the 'revival' of saby as practiced by IS stating:

After all this, the ramblers dare to extend their tongues with false rumors and accusations so as to disfigure the great shar'î ruling and pure prophetic Sunnah titled "saby"? After all this, saby becomes fornication and tasarrī (taking a slave-girl as a concubine) becomes rape? If only we'd heard these falsehoods from the kuffār who are ignorant of our religion. Instead we hear it from those associated with our Ummah, those whose names are Muhammad, Ibrāhīm, and 'Alī!... As for the slave-girl that was taken by the swords of men following the cheerful warrior (Muhammad - sallallāhu 'alayhi wa sallam), then her enslavement is in opposition to human rights and copulation with her is rape?! What is wrong with you? How do you make such a judgment? What is your religion? What is your law? Rather, tell me who is your lord? Never did the Khilāfah's soldiers revive a Sunnah or extinguish a bid'ah except that you shouted with lewdness and heresy! liv 
In relation to the appropriation of the salaf for the purpose of religiously justifying acts of violence, several examples from Daqib Magazine can be considered. In issue seven on the page 18, there is a reproduction of a latter attributed to the first Caliph Abu Bakr from Tabari's Tarikh, titled 'An Explicit Ultimatum from the Salaf to the Apostates', in which the Caliph writes to the apostate tribes after Muhammad's death as follows:

It has reached me that some of you turned back from their religion after accepting Islam and acting in accordance with it... And if they [the apostates] perform adhān, then restrain yourselves from attacking them until you ask them to deliver what is obligatory upon them [the $z a k \bar{a} h]$. If they refuse, then rush to kill them. ${ }^{\text {lv }}$

The letter is used in a manner to suggest that the Muslim Brotherhood, by taking part in electoral politics and participating in United Nations fora, are engaging in acts which are tantamount to apostasy, and hence are liable for the same punishment.

In the same issue on p. 21, an article titled "Islam is a Religion of the Sword and not of Pacifism" some western Muslim religious leaders are criticized, if not ridiculed for painting a picture of a pacifist Islam to which the following response appears:

Alī Ibn Abī Tālib (radiyallāhu 'anh) said, ‘Allah’s Messenger (sallallāhu 'alayhi wa sallam) was sent with four swords: a sword for the mushrikin, \{And when the sacred months have passed, then kill the mushrikīn wherever you find them] [At-Tawbah: 
$5^{\text {lvi }}$, a sword for Ahlul-Kitāb, \{Fight those who do not believe in Allah or in the Last Day and who do not consider unlawful what Allah and His Messenger have made unlawful and who do not adopt the religion of truth from those who were given the Book - [fight them] until they give the jizyah willingly while they are humbled\} [AtTawbah: 29], a sword for the munāfiqīn, \{O Prophet, fight against the kuffār and the munāfiqīn\} [At-Tawbah: 73], and a sword for the bughāt (rebellious aggressors), \{Then fight against the group that commits baghy (aggression) until it returns to the ordinance of Allah\} [Al-Hujurāt: 9]' [Tafsīr Ibn Kathīr]. He also revealed the sword against the apostates, $\{\mathrm{O}$ you who have believed, whoever of you should revert from his religion-Allah will bring forth a people He will love and who will love Him [who are] humble toward the believers, mighty against the disbelievers; they strive in the cause of Allah and do not fear the blame of a critic\} [Al-Mā'idah: 54]. This verse is a fundamental basis for the obligation to fight against the apostate parties. At-Tabarī reported in his tafsīr that amongst the Salaf, 'Alī Ibn Abī Tālib, Qatādah, al-Hasan alBasrī, ad-Dahhāk, and Ibn Jurayj said this verse encompassed Abū Bakr (Allah's sword against apostasy), his companions (radiyallāhu 'anhum), and their war against the apostates - the followers of Musaylamah al-Kadhdhāb and those who resisted the obligation of zakāh. lvii

On the same page, Ibn Taymiyya is cited (from his work al-Majmu' al Fatawa) to justify the argument that the basis of religion was guidance accompanied by the sword." lviii 
A final example is from the ninth issue of Dabiq ${ }^{\text {lix }}$ that features an article that discusses the concept and the benefits of the practice of ribat. ${ }^{\mathrm{lx}}$ The author justifies this practice on the basis of the following:

- several Qur'anic verses

- classical Quranic exegesis (Tafsir At-Tabari; Tafsir Ibn Al-Mundhir),

- several hadith (from Malink's Muwatta; Bukhari’s Sahih and Muslim's Sahih)

- a number of ahl-hadith scholars including (Ibn Taymiyya, Imam Ahmad ibn Hanbal, Ibn al-Qayyim and others)

There is also a specific section of the article titled "The Salaf and the Forty Days of Ribat" where the case is made that the practice of ribat is justified specifically as the practice of the salaf and that engaging in ribat is "upon the methodology of the Salaf". xi

From the above examples we can deduce that all of the dimensions of the salafi worldview are heavily present and employed by the proponents of IS ideology to justify their practices some of which have clear violence-based implications. For example, by making many references to the Qur'an and the hadith, the proponents of IS clearly place an enormous amount of emphasis on what they consider to be the views which are in continuity with the isnad paradigm of the turath. Furthermore, in terms their manhaj, it is clearly evident that the proponents of IS ideology often cite the scholars associated with the Hanbali / ahl al-hadith (or the historicoempirical method) school of thought such as Ibn Taymiyya, Ibn Qayyim, Al-Hanbali, Imam Ahmad, 'Abd al Wahhab and others. Furthermore, as we saw in the cases of enslavement of non-Muslim women and punishment for apostasy, the views /interpretations of the IS ideology 
are often justified with references to the practices of the salaf and the Companions who are, consistent with the 'adalat al-sahaba and the sacred past/ retrogressive history elements of the salafi worldview, considered as ultimate points of reference when it comes to ascertaining the legitimacy and authoritativeness of Islamic beliefs and practices. Moreover, in all of the examples discussed above the justifications proffered by the proponents of IS ideology clearly consider the practices established by the early generations of Muslims as a priori universally binding to all Muslims for all times.

What matters most from the perspective of the aims of this article is not necessarily the question of whether or not the proponents of the IS interpretations of Islam are citing the Qur'an and hadith de-contextually or selectively ${ }^{\text {lxii }}$, or whether or not their appropriation of Hanbali /ahl al-hadith scholars is doing justice to their views or whether or not their appropriation of the Companions or the salaf are indeed representative but the actual mode of reasoning employed and the epistemological and hermeneutical process their inform their construction of authority and normativity. Based on the above evidence and analysis it is clearly evident that the mode of reasoning and the construction of authority employed by the IS proponents shares the same salafi worldview as does mainstream Sunnism. One of the implications of this finding is that theological rebuttals penned by mainstream Sunni scholars have significant hermeneutical limits and make it very difficult to render the interpretations of jihadist-salafi groups like the IS as hermeneutically unreasonable if mainstream Sunni hermeneutical commitments embodied in the salafi worldview are taken as normative. Hence, the persuasive power of mainstream Sunni critique of jihadist-salafism based on scriptural hermeneutics on issues such as those discussed above, but also others ${ }^{\text {xiii }}$, is greatly impaired. 
Hence, it is not surprising that for example, in mainstream Sunnism, apostasy is considered to be punishable by death although differences in opinion exist as to what constitutes the acts of apostasy or what its basis is i.e. religious or political. ${ }^{\text {lxiv }}$ Or, to provide another example, it is not surprising that there are many shared beliefs laws and practices pertaining to role and status of women in society, including dress codes, between the proponents of mainstream Sunnism and those associated with the IS ideology. ${ }^{1 \times v}$ I argue that these are the result of their shared subscription to the salafi worldview as described here.

If mainstream Sunnism was to render the views of Jihadist-salafi grounds such as the IS hermeneutically unreasonable it would need to adopt a significantly different approach to conceptualising the concept of turath by moving away from its emphasis on isnad and a heavily textualist epistemology, and also rethink other aspects of what we described as the salafi worldview. It would, at the minimum, have do adopt a much more contextualist approach to the conceptualisation and interpretation of the Qur'an and the hadith, it would need to rethink the concept of Sunna and its relationship with the methodologies associated with authenticating the hadith and it would need to subscribe to a rationalist Islamic theology and theory of ethics. ${ }^{\text {xvi }}$

\section{CONCLUSION}

The concept of the salafi worldview in Islamic intellectual history has a number of dimensions and performs specific functions that are fundamental to mainstream Sunnism doctrinally, epistemologically and hermeneutically. Based on the evidence presented from the Dabiq 
magazine, the justifications and the mode of reasoning adopted by the IS proponents are in complete harmony with that underpinning the salafi worldview. Therefore, a considerable degree of hermeneutical affinity between mainstream traditionalist Sunnism and that of the IS exist. As such the former is not able to render the interpretations of the latter as hermeneutically unreasonable as they both share the same "salafi worldview". Hence, by subscribing to the "salafi worldview" mainstream Sunnism has significant hermeneutical limits when it comes to mounting theological rebuttals of the many beliefs and practices jihadist-salafist groups like the IS subscribe to including those pertaining to apostasy, enslavement of female war captives and the role and the status of women in society. This author has also identified the necessary interpretational approaches mainstream Sunnism would need to adopt to overcome these limitations. Some contemporary Muslim scholar associated with progressive Muslim thought have provided sophisticated arguments, including on the basis of scriptural reasoning, as to why these alternative interpretational approaches are not only authentic but also are a truer expression of the ideals behind the Islamic worldview and its fountainhead, the Qur'an and the Sunna. I hope that mainstream Sunnism will also move in this direction.

\footnotetext{
${ }^{i}$ By the phrase 'mainstream Sunni scholars I mean those scholars who consider themselves to be part of or belong to one of the major school of thought in Sunni theology (Maturidi, Ash'ari, Ahl- al hadith) and jurisprudence (Maliki, Shafi' 'i, Hanafi and Hanbali). They usually refer to themselves as the ahl-al sunna wa'l jama' $a$. The boundaries (and contestations) of mainstream Sunnism have recently been debated by the gathering of mainstream Sunni scholars in Chechenia in 2016. https://en.wikipedia.org/wiki/2016_international_conference_on_Sunni_Islam_in_Grozny

ii Muhammad Afifi Al-Akiti, Defending the Transgressed by Censuring the Reckless against the Killing of Civilians, (Birmingham, 2005); Tahir Al-Qadri, Fatwa on terrorism and Suicide Bombings, (London: Minhaj ulQur'an Publications,2010).
} 
iii http://binbayyah.net/english/fatwa-response-to-isis/; Muhammad Al-Yaqubi, Refuting ISIS: A Rebuttal Of Its Religious And Ideological Foundations ( London : Sacred Knowledge, 2015); http://lettertobaghdadi.com/translations.php

${ }^{\text {iv }}$ Ibrahim Abu Rab'i, Intellectual Origins of Islamic Resurgence in the Arab World, (New York: SUNY Press, 1996), 42. This broader definition of turath is associated with the work of Muslim scholars such as M.A. Al-Jabiri, H.N. Abu Zayd and H. Hanafi. See Ismail, Mansoor, "The Unpredictability of the Past: Turath and Hermeneutics", PhD thesis, University of California, Los Angeles, 2000.

${ }^{\mathrm{v}}$ Binyamin Abrahamov, Islamic theology: traditionalism and rationalism, (Edinburgh: Edinburgh University Press, 1998), p.vii.

${ }^{v i}$ William Graham, “Traditionalism in Islam: an essay in interpretation'. Journal of Interdisciplinary History 23 (1993), pp. 495-522, p.501.

vii Ibid, p. 506.

viii Adis Duderija, Constructing religiously ideal 'believer' and 'Muslim woman' concepts: neo-traditional Salafi and progressive Muslim methods of interpretation (Manahij), (New York: Palgrave Series in Islamic Theology, Law and History, Palgrave).

ix Ashk Dahlen, Islamic law, epistemology and modernity: legal philosophy in contemporary Iran, (New York: Routledge, 2003).

${ }^{\mathrm{x}}$ Richard C. Martin, Mark R. Woodward, Dwi S. Atmaja, Defenders of Reason In Islam: Mu'tazilism and Rational Theology from Medieval School to Modern Symbol, (Oxford : Oneworld, 1997).

xi This 'hermeneutical stability' coincides conceptually and chronologically with the acceptance of the idea of taqlid based hermeneutic among the madhahib and the recognition of all of them being co-constitutive of the Sunni orthodoxy. Wael Hallaq, Authority, Continuity and Change in Islamic Law (Cambridge: Cambridge University Press,2004)

xii Dahlen, Islamic law, p. 67.

xiii Duderija, Constructing.

xiv Ibid, pp.77-78.

${ }^{x v}$ Duderija, Constructing.

xvi Dahlen, Islamic law.

xvii Suleiman Mourad, Early Islam between myth and history: Al-Hasan al-Basrī (d. 1101. 728 ce) and the formation of his legacy in classical Islamic thought (Leiden, Brill,2006), p.199.; Edmond Chaumont, "al-Salaf Wa-1-khalaf", in: Encyclopédie de l'Islam. Consulted online on 17 May 2018

$<\mathrm{http}: / /$ dx.doi.org/10.1163/9789004206106_eifo_SIM_6515>

xviii Ignaz Goldziher, Muslim Studies, vol. 2, (trans. Barber and Stern, London: George Allen \&Unwin Ltd., 1971), p. 31.

xix Khalīl b. Aybak As-Safadī, al-Wāfì bi'l-Wafayāt, (Beirut: Dār Ihyā Turath al-'Arabī Print 2000 CE), eds. Ahmad al-Arna'ūt and Turkī Mustafā.; Henri Lauziere, The making of Salafi worldview: Islamic reform in the twentieth century, (New York: Columbia University Press, 2015), Introduction.

${ }^{x x}$ Ovamir Anjum, "Cultural memory of the pious ancestors (Salaf) in al-Ghazālī”, Numen, vol. 58, pp. 344-374, 2011, p.347.

${ }^{x x i}$ Ahmed Souaiaia, A 2006, The function of orality in Islamic law and practices: verbalizing meaning, (New York: Edwin Meller Press, 2006), pp.163-164.

xxii Wael Hallaq, Authority, continuity and change in Islamic law, (Cambridge: Cambridge University Press, 2001) p. 257.

xxiii Ibid, p.239. 
xxiv Daniel Brown, Rethinking tradition in modern Islamic thought (Cambridge: Cambridge University Press, 1996) p.20.

xxv Ibid, pp.28-29.

xxvi James Robson, “Tradition: investigation and classification”, Muslim World, vol. 41, pp. 98-

112,1951, p.101.

xxvii Gibril Haddad, Albani and his friends: a concise guide to the Salafi movement, (Aqsa

Publications, Birmingham, 2004) pp. xiii-xiv.

xxviii Joseph Van Vass, The flowering of Muslim theology, trans. JM Todd, (Cambridge: Harvard University Press, 2006), p. 117.

${ }^{x x i x}$ Anjum, "Cultural memory of the pious ancestors (Salaf)", p. 246.

${ }^{\mathrm{xxx}}$ Mourad, Early Islam between myth and history, pp.199-200.

xxxii Duderija, Constructing.

xxxiii Anjum, 'Cultural memory of the pious ancestors (Salaf), p. 344.

${ }^{\text {xxxiv }}$ Amr Osman, 'Adālat al-Șaḥāba: The Construction of a Doctrine', Arabica, vol. 60, 2011, pp. 272-305.

xxxv Adis Duderija, The Sunna and its Status in Islamic law: The Search for a Sound Hadith (New York: Palgrave, 2015), Introduction,1-13..

xxxvi Chaumont, "al-Salaf Wa-1-khalaf".

xxxvii Graham, “Traditionalism in Islam”, p.501.

xxxviii Duderija, Constructing , 49-69.

xxxix Reinhart Schulze, A modern history of the Muslim world, (New York University Press, New York, 2000), p. 18.

xl Osman, 'Adālat al-Șahāāba, 278.

xli Souaiaia, The function of orality.

xlii In this context invoking God's curse on those who are incorrect in their understanding and practice of Islam.

xliii Dabiq Magazine, Issue Two, 20-22. https://azelin.files.wordpress.com/2014/07/islamic-state-e2809cdc481biqmagazine-2e280b3.pdf

xliv Ibid,29.

xlv Dabiq, Issue One, 20-28. https://azelin.files.wordpress.com/2014/07/islamic-state-22dc481biq-magazine-122.pdf

${ }^{x l v i}$ Dabiq , Issue Three, 25-32. https://clarionproject.org/docs/isis-isil-islamic-state-magazine-Issue-3-the-call-tohijrah.pdf

xlvii Dabiq, Issue Four,32-37. https://clarionproject.org/docs/isis-isil-islamic-state-magazine-issue+8-sharia-alonewill-rule-africa.pdf

xlviii ISIS Enshrines a Theology of Rape, The New York Times, https://www.nytimes.com/2015/08/14/world/middleeast/isis-enshrines-a-theology-of-rape.html

xlix By that they mean mainstream classical jurists as evident from the main text below.

${ }^{1}$ Ibid, 15. This interpretation is in accordance with the research by Friedmann (2003, 136-137).

li Ibid.

lii Ibid,15-17.

liii Dabiq, Issue Nine, 44-45.https://clarionproject.org/docs/isis-isil-islamic-state-magazine-issue+9-they-plot-andallah-plots-sex-slavery.pdf

liv Ibid,48-49.

${ }^{\text {Iv }}$ Dabiq, Issue Seven, 18.https://clarionproject.org/docs/islamic-state-dabiq-magazine-issue-7-from-hypocrisy-toapostasy.pdf.

lvi This is a reference to Qur'anic verses used to justify this interpretation of the narration.

lvii Ibid, 21.

lviii Ibid.

lix Dabiq Issue Nine, https://clarionproject.org/docs/isis-isil-islamic-state-magazine-issue+9-they-plot-and-allahplots-sex-slavery.pdf

${ }^{1 x}$ Outlasting the enemy in patience in the context of war strategies. 
lxi Ibid,11.

lxiii Adis Duderija, "The Islamic State (IS) as the proponents of Neo-Ahl al Hadith Manhaj on gender-related issues, Hawwa, vol. 13, 2015, pp. 198-240.

lxiv Yohanan Friedmann, Tolerance and Coercion in Islam: Interfaith Relations in the Muslim Tradition. Cambridge: Cambridge University Press,2003), pp.121-159; Rudolph Peters, Crime and punishment in Islamic law: theory and practice from the $16^{\text {th }}$ to the $20^{\text {th }}$ century, (Cambridge University Press, Cambridge), pp. 64-65.

lxv Duderija, "The Islamic State (IS) as the proponents of Neo-Ahl al Hadith".

Ixvi In fact, these interpretational approaches/mechanisms are constitutive of the theory of progressive Islam. See Adis Duderija, The imperatives of progressive Islam, (New York: Routledge, 2017). 